Brit. J. prev. soc. Med. (1969), 23, 263-266

\title{
PREVALENCE OF SYMPTOMS OF URINARY TRACT INFECTION IN WOMEN
}

\author{
BY \\ W. E. WATERS, M.B., B.S., D.I.H. \\ Member of the Scientific Staff, Medical Research Council Epidemiological Research Unit (South Wales)
}

Infections of the urinary tract are among the most frequent of all infections, especially in women (Kass, 1956). Most studies of the prevalence of symptoms referable to the urinary tract have been based on patients consulting their practitioners. However, such symptoms do not always lead to a woman attending a doctor. There do not appear to be any published estimates of the prevalence of urinary tract symptoms in representative samples of the general population in this country.

Urinary tract infections are of importance in themselves as a troublesome cause of discomfort and sometimes of ill-health. They may also progress to chronic pyelonephritis and hence be aetiologically related to the morbidity and mortality of chronic renal failure and hypertension. At present there is considerable controversy as to how often acute urinary tract infections do lead to renal damage and how often renal failure is an end result of acute urinary tract infections. An assessment of the prevalence of urinary tract infection in the general population is an important step towards determining their importance in this context.

\section{Method}

All women aged 20 to 64 years inclusive living in a defined area in the Rhondda valley in South Wales in 1967 were invited to attend a survey which was mainly haematological. In addition, every woman was asked questions about several aspects of health including symptoms referable to the urinary tract. The questionnaires were administered by four female interviewers who had been trained for the survey. Women attending the survey centre were allocated to a particular interviewer by reference to a preprepared sheet on which the interviewers were randomized within blocks of four (or three on a number of days on which one was absent, as the interviewers were not all available throughout the whole survey period). During the last few days at the survey centre, when only a small number of subjects was seen, the interviewers were not randomized and these data are analysed separately. Some women, unable or unwilling to come to the survey centre, were later visited by one or other of the interviewers at home. Questions were asked about dysuria (defined as 'any burning or pain on passing water'), frequency of micturition, and other symptoms associated with infections of the urinary tract. All women with dysuria were asked whether or not they had consulted their doctors with this symptom. The haematological data, and some tests of renal function on various sub-samples of this population, will be presented elsewhere.

\section{RESULTS}

Completed questionnaires were obtained from 2,933 women aged $20-64$ years (over $86 \%$ of all such women in the survey area). For the interviews which were randomized the proportion of women who gave a history of dysuria during the previous year (Table I) varied between $18.6 \%$ and $26.8 \%$ with the four interviewers. Although the differences are statistically significant, three of the four interviewers obtained

TABLE I

DETAILS OF NUMBER OF WOMEN AGED 20-64 SEEN AND NUMBER WITH DYSURIA IN PREVIOUS YEAR

\begin{tabular}{|c|c|c|c|c|c|c|c|c|}
\hline & \multicolumn{4}{|c|}{ Interviewer Randomized* } & \multicolumn{3}{|c|}{ Interviewer not Randomized } & \multirow{2}{*}{ Total } \\
\hline & $\mathbf{A}$ & $\mathbf{B}$ & $\mathbf{C}$ & $\mathbf{D}$ & $\begin{array}{l}\text { Survey } \\
\text { Centre }\end{array}$ & $\begin{array}{c}\text { Home } \\
\text { Visit }\end{array}$ & Pregnant & \\
\hline $\begin{array}{l}\text { No. interviewed } \\
\text { No. with dysuria in past year } \\
\text { Percentage }\end{array}$ & $\begin{array}{l}744 \\
160 \\
21 \cdot 5\end{array}$ & $\begin{array}{l}668 \\
179 \\
26 \cdot 8\end{array}$ & $\begin{array}{c}774 \\
153 \\
19 \cdot 8\end{array}$ & $\begin{array}{l}516 \\
96 \\
18 \cdot 6\end{array}$ & $\begin{array}{l}69 \\
16 \\
23 \cdot 2\end{array}$ & $\begin{array}{l}76 \\
17 \\
22 \cdot 4\end{array}$ & $\begin{array}{l}86 \\
18 \\
20.9\end{array}$ & $\begin{array}{r}2,933 \\
639 \\
21 \cdot 8\end{array}$ \\
\hline
\end{tabular}

$x^{2}$ (between observers) $=14 \cdot 8 ;$ D.F. $=3 ; P<0.01$. 
estimates of dysuria prevalence which varied by only $3 \%$. Of the 86 women known to be pregnant at the time of the survey, $18(20.9 \%)$ had had dysuria during the previous year. The women seen at the centre towards the end of the survey, and those who were later visited in their homes, also had similar prevalences of dysuria. Overall $21.8 \%$ of women said that they had had dysuria during the previous year. Age had no significant effect on this proportion, nor on the proportion $(9.8 \%$ who had had dysuria for a total of more than two weeks during the previous year (Table II and Figure). Of the women known to be pregnant, only seven ( $8 \%$ ) had had dysuria for more than two weeks in the previous year.

The effects of marital state and parity on the proportion of women with dysuria during the previous year are shown in Table III. More married women had had dysuria than those never married and this difference is statistically significant $\left(\chi^{2}=\right.$ 11.94; d.f. $=1 ; P<0.01)$. Among the married women the increased prevalence of dysuria in those who had been pregnant, compared with the married nulliparous women, is not statistically significant $\left(\chi^{2}=1.39 ;\right.$ d.f. $\left.=1 ; 0.3>P>0.2\right)$. Age had no significant effect on these proportions.

The number of women who said that they had consulted their general practitioner because of dysuria during the previous year is shown in Table IV and in the Figure. Nearly $10 \%$ of all women had consulted their doctors during this time but the proportion was significantly higher in the younger age groups $(\mathrm{P}<0.001)$.

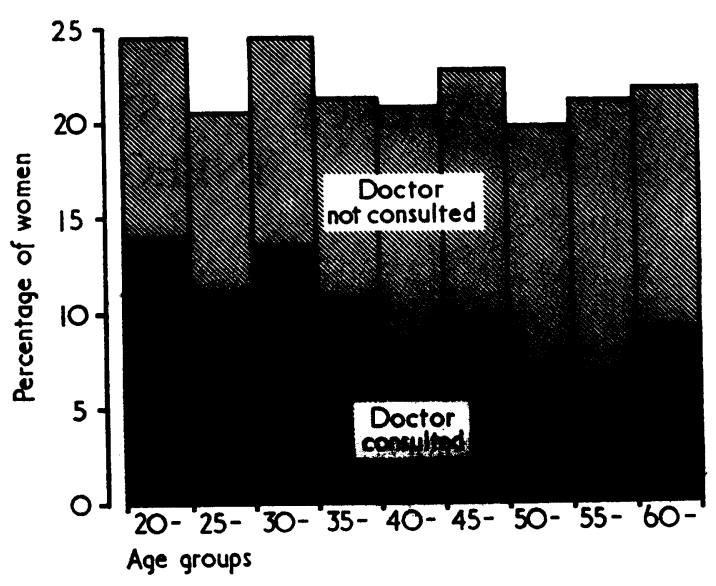

Frourb.-Proportion of women aged 20-64 years with dysuria in the previous year and the proportion who consulted a general practitioner.

The prevalence of symptoms that had occurred at any time in life (Table V) showed no significant age effect over the range studied. Many older women, however, said that the first symptoms had occurred in recent years. These findings suggest that memory for these symptoms in the past is poor and that between 20 and 64 years as many women forget the symptoms as experienced them for the first time. Such prevalences are therefore almost certainly only minimum figures. Nearly $50 \%$ of women said that they had had dysuria at some time. The first attack was said to have occurred during or within two weeks of a pregnancy in $368(12.5 \%$ of all women

Table II

DYSURIA IN PREVIOUS YEAR AND AGE IN 2,933 WOMEN AGED 20-64 YEARS

\begin{tabular}{|c|c|c|c|c|c|c|c|c|c|c|}
\hline & \multicolumn{10}{|c|}{ Age (years) } \\
\hline & 20 & 25 & 30 & $35-$ & 40 & $45-$ & $50-$ & 55- & 60 & Total \\
\hline Total No. interviewed & 294 & 333 & 344 & 301 & 352 & 376 & 360 & 291 & 282 & 2,933 \\
\hline $\begin{array}{l}\text { Dysuria in past year" } \\
\text { No. } \\
\text { Percentage }\end{array}$ & $\begin{array}{l}72 \\
24 \cdot 5\end{array}$ & $\begin{array}{l}68 \\
20 \cdot 4\end{array}$ & $\begin{array}{l}84 \\
24 \cdot 4\end{array}$ & 64 & $\begin{array}{l}73 \\
20 \cdot 7\end{array}$ & $\begin{array}{l}85 \\
22 \cdot 6\end{array}$ & $\begin{array}{l}71 \\
19 \cdot 7\end{array}$ & $\begin{array}{l}61 \\
21 \cdot 0\end{array}$ & $\begin{array}{l}61 \\
21 \cdot 6\end{array}$ & 239 \\
\hline $\begin{array}{l}\text { Dysuria for > } 2 \text { weeks in past year } \\
\text { No. } \\
\text { Percentage }\end{array}$ & 26 & $\begin{array}{l}36 \\
10 \cdot 8\end{array}$ & $\begin{array}{l}36 \\
10 \cdot 5\end{array}$ & $\stackrel{29}{9 \cdot 6}$ & $\begin{array}{l}29 \\
8 \cdot 2\end{array}$ & 34 & $\stackrel{33}{9 \cdot 2}$ & $\begin{array}{l}31 \\
10 \cdot 7\end{array}$ & $\begin{array}{l}33 \\
11 \cdot 7\end{array}$ & $\underset{9 \cdot 8}{287}$ \\
\hline
\end{tabular}

$x^{2}=4.47 ;$ D.F. $=8 ; 0.90>P>0.80$. For linear trend $\chi^{2}$ (1.D.F.) $=0.98 ;$ Not significant

$* x^{2}=3.65 ;$ D.F. $=8 ; 0.90>P>0.80$. No significant linear trend possible

TABLB III

DYSURIA IN PREVIOUS YEAR, MARTTAL STATE, AND PARITY OF 2,933 WOMEN AGED 20-64 YEARS

\begin{tabular}{|c|c|c|c|c|c|c|c|c|}
\hline \multicolumn{3}{|c|}{ Never Married } & \multicolumn{3}{|c|}{ Married-No Pregnancies } & \multicolumn{3}{|c|}{ Married-Parous } \\
\hline \multirow{2}{*}{ Total } & \multicolumn{2}{|c|}{ Dysuria } & \multirow{2}{*}{ Total } & \multicolumn{2}{|c|}{ Dysuria } & \multirow{2}{*}{ Total } & \multicolumn{2}{|c|}{ Dyeuria } \\
\hline & No. & $\%$ & & No. & $\%$ & & No. & $\%$ \\
\hline 295 & 41 & 13.9 & 249 & 49 & 19.7 & 2,389 & 549 & $23 \cdot 0$ \\
\hline
\end{tabular}


TABLE IV

NUMBER OF WOMEN WHO CONSULTED A GENERAL PRACTITIONER BECAUSE OF DYSURIA (BASED ON 2,933 WOMEN AGED 20-64 YEARS)

\begin{tabular}{|c|c|c|c|c|c|c|c|c|c|c|}
\hline & \multicolumn{10}{|c|}{ Age at Time of Interview } \\
\hline & $20-$ & 25 & 30 & 35 & 40 & 45 & $50-$ & $55-$ & $60-$ & Total \\
\hline $\begin{array}{l}\text { In past year" } \\
\text { No. } \\
\text { Percentage }\end{array}$ & $\begin{array}{l}41 \\
13.9\end{array}$ & $\begin{array}{l}37 \\
11 \cdot 1\end{array}$ & $\begin{array}{l}46 \\
13 \cdot 4\end{array}$ & $\begin{array}{l}32 \\
10.6\end{array}$ & $\begin{array}{l}28 \\
8.0\end{array}$ & $\begin{array}{c}35 \\
9 \cdot 3\end{array}$ & ${ }_{6.7}^{24}$ & $\stackrel{18}{6.2}$ & $\begin{array}{c}25 \\
8.9\end{array}$ & $\stackrel{286}{9 \cdot 8}$ \\
\hline
\end{tabular}

$x^{2}=21.69 ;$ D.F. $=8 ; 0.01>P>0.001$

For linear trend $\chi^{i}$ (1.D.F.) $=14.9 ; P<0.001$

TABLE V

PREVALENCES AT ANY TIME IN LIFE FOR 2,933 WOMEN AGED 20-64 YEARS

\begin{tabular}{l|c|c}
\hline \multicolumn{1}{c|}{ Symptom } & No. & Percentage \\
\hline Dysuria & 1,415 & 48.2 \\
$\begin{array}{l}\text { Frequency of micturition with } \\
\text { dysuria }\end{array}$ & 926 & 31.6 \\
$\begin{array}{l}\text { Pyrexia with dysuria } \\
\text { Haematuria }\end{array}$ & 473 & 16.1 \\
Doctor consulted for dysuria & 202 & 6.9 \\
\hline
\end{tabular}

seen), and 53 women (1.8\%) dated their first attack to childhood (under 15 years of age).

\section{Discussion}

These data from a community survey indicate that symptoms of urinary tract infection are common in women aged 20-64 years with $21.8 \%$ having had dysuria within the previous year. Previously published data on the prevalence of urinary tract infection in Great Britain have been based on patients consulting their general practitioners. The prevalences reported by Logan and Cushion (1958), Loudon and Greenhalgh (1962), Fry, Dillane, Joiner, and Williams (1962) and Mond, Percival, Williams, and Brumfitt (1965) are considerably lower than the proportion of women in this study who said they had attended their doctors because of these symptoms (Table IV and Figure). However, these earlier studies, except that of Logan and Cushion who do not state the diagnostic criteria they used, insisted on positive bacterial cultures from specimens of urine to confirm the diagnosis. Eastwood, Bruce, and Wren (1965), using clinical criteria, found a prevalence of urinary tract infection similar to the proportion in the present community survey who had attended their doctors (Table IV and Figure) except that they found an even higher prevalence in younger women. Loudon and Greenhalgh (1962), Fry et al. (1962), and Eastwood et al. (1965) all found that younger women (up to 30 or 35 years) are more likely to attend their doctor with urinary tract infections than older women. A similar trend, which is statistically significant, is evident in the present study (Table IV and Figure). However, when the prevalence of dysuria in all women in the community is considered (Table II and Figure), age has no significant effect.

This survey did not set out to compare the prevalence of dysuria during pregnancy with that in non-pregnant women. However, the finding that only $18(20.9 \%)$ of the 86 women known to be pregnant at the time of the survey had had dysuria in the previous year is surprising as this figure is actually lower than that for non-pregnant women. Only seven $(8 \%)$ of these pregnant women had had dysuria for more than two weeks during the previous year and this prevalence also is slightly less than that for all the women.

In a cross-sectional epidemiological study of urinary tract symptoms it is impossible to know how many subjects would have had supporting evidence of urinary infection. Many patients attending their general practitioner with symptoms of urinary tract infection have mid-stream specimens of urine which are normal in respect of both bacterial and cellular content (Eastwood et al., 1965). It seems reasonable to accept that dysuria is nearly always related to inflammation at some level of the urinary tract. Although Gray and Pingelton (1956) have suggested that many cases with negative urine findings are caused by nervous tension, Mond et al. (1965) give evidence that many such patients have a urethritis without infection of the urine. The localization of the anatomical site of the inflammation is often difficult clinically and probably impossible in a retrospective interview. However, the seriousness of the infection depends mainly on whether or not there is renal involvement. Eastwood et al. (1965) found renal tenderness, regarded as prima facie evidence of kidney inflammation, in $55.3 \%$ of women with symptoms of urinary tract infection attending their doctor. In addition, Percival, Brumfitt, and de Louvois (1964), using serum-antibody levels, found evidence of renal involvement in 8 out of $31(26 \%)$ domiciliary patients in whom symptoms were con- 
fined to the lower urinary tract. If the kidneys are not involved, urinary tract infections are usually diagnosed as cystitis (see Logan and Cushion, 1958) although in fact the bladder mucosa is usually normal on cystoscopy and the condition should, according to Hanley (1963), be termed a urethritis or at most a urethro-trigonitis. The main importance of this condition is that even in an anatomically normal urinary tract it may lead to a pyelitis by an ascending infection due to ureteric reflux (Hanley, 1962). Thus, of women presenting for medical treatment with dysuria, it seems that a considerable number have clinical evidence of renal involvement, a further group may have such involvement although it is not clinically evident, and all the remainder have a condition that may lead to a kidney infection. Clinically, it is often hoped that effective treatment of acute urinary tract infections will reduce the morbidity and mortality of chronic pyelonephritis. The data presented here emphasized the large number of women who may have acute infections and that many do not seek medical attention. At most, a small minority of these women could be expected to progress to chronic renal failure. Further research is required to identify the characteristics of any such group.

\section{SUMMARY}

During a community survey 2,933 women aged 20 to 64 years were asked questions about symptoms of urinary tract infection. Six hundred and thirtynine $(21.8 \%)$ had had dysuria (defined as burning or pain on passing water) within the previous year. In 287 women $(9.8 \%)$ the dysuria had lasted for a total of more than two weeks during the year. Neither of these prevalences varied significantly with age in the range studied. Dysuria was significantly more common in the married than in the single women. Significantly more women in the younger age-groups had consulted their doctors because of these symptoms.

I thank Dr. A. L. Cochrane, Director of Epidemiological Research Unit, and other staff for help during this research.

\section{REFERENCES}

EastwoOd, N. B., BRUCE, R. G., and WREN, W. J. (1965). Prevalence of inflammation of the urinary tract. J. Coll. gen. Practit., 10, 257.

Fry, J., Dillane, J. B., Joiner, C. L., and Williams, J. D. (1962). Acute urinary infections, their course and outcome in general practice with special reference to chronic pyelonephritis. Lancet, 1, 1318.

Gray, L. A., and Pingelton, W. B. (1956). Pathological lesions of the female urethra. J. Amer. med. Ass., 162, 1361.

HANLEY, H. G. (1962). Transient stasis and reflux in the lower ureter. Brit. J. Urol., 34, 283.

(1963). Pyelonephritis and lower urinary-tract inflammation. Lancet, 1, 22.

KASS, E. H. (1956). Asymptomatic infections of the urinary tract. Trans. Ass. Amer. Phycns., 69, 56.

Logan, W. P. D., and Cushion, A. A. (1958). Morbidity Statistics from General Practice, General Register Office; Studies on Medical and Population Subjects. No. 14. H.M.S.O., London.

LOUDON, I. S. L., and GREENHALGH, G. P. (1962). Urinary tract infections in general practice. Lancet, 2, 1246.

Mond, N. C., Perctval, A., Williams, J. D., and BRUMfIT, W. (1965). Presentation, diagnosis, and treatment of urinary-tract infections in general practice. Ibid., 1, 514.

Percival, A., Brumfitt, W., and de Louvois, J. (1964). Serum-antibody levels as an indication of clinically inapparent pyelonephritis. Ibid., 2, 1027. 